УДК 373.53:37.016:91

DOI: $10.37026 / 2520-6427-2020-104-4-37-41$

\section{Григорій ПУСТОВІТ,}

доктор педагогічних наук, професор, професор кафедри природничо-математичної освіти Рівненського обласного інституту післядипломної педагогічної освіти

\section{Ярослав СИВОХОП,}

кандидат педагогічних наук, доцент, директор Закарпатського інституту післядипломної педагогічної освіти, м. Ужгород

\title{
УПРОВАДЖЕННЯ УТЕМ-ОСВІТИ НА УРОКАХ ГЕОГРАФІЇ: ДИДАКТИЧНА СКЛАДОВА
}

У статті схарактеризовано сутнісні ознаки дидактичної складової упровадження STEM-освіти в сучасних закладах загальної середньої освіти, зокрема на уроках географії. Метою ії запровадження $\epsilon$ гармонійний розвиток особистості завдяки формуванню провідних життєво важливих компетентностей, природничо-наукової картини світу, світоглядних позииій $і$ життевих иінностей. Виокремлено й частково розкрито нормативну основу та значення цьього підходу у розвитку освітнього простору держави як провідної складової державної політики з підвищення рівня конкурентоспроможності національної системи освіти. Схарактеризовано теоретико-прикладний аспект провідних наукових підходів функиіонування STEM-освіти: мультидисииплінарного, плюридисииплінарного, інтердисииплінарного, трансдисииплінарного. У межах останнього підходу актуальними залишаються традииійні дидактичні наукові підходи до побудови навчального змісту за умови їх орієнтації, в першу чергу, на активну самостійну і творчу діяльність, щуо є провідною у проиесах навчання та формування в учнів умінь і навичок самоосвіти, котрі є ключовими в переліку провідних життєвих $і$ кар'єрних «Навичок ХХІ століття». Такими традиційними дидактичними підходами до конструювання навчального змісту $i$ самостійноі діяльності учнів є: міжпредметний, інтеграційний, диференціачіï та індивідуалізації. Розкрито й схарактеризовано сутнісні ознаки специфічних якостей, які мають засвоїти учні у процесі здобуття STEM-освіти: формування потреби в навчанні, формування мотивачії до навчання, формування і розвиток інтересу. Публікацію другої частини статті буде здійснено у наступному номері журналу.

Ключові слова: STEM-освіта, дидактична складова, заклади загальної середньої освіти, компетентності, наукові підходи, учні.

In the article the author describes the essential features of the didactic component of the introduction of STEM-education in modern general secondary education institutions, in particular in geography lessons. The purpose of which is the harmonious development of personality through the formation of leading vital competencies, natural science picture, worldview and life values.
The normative basis and significance of this approach in the development of educational space of the state education system. The theoretical and applied aspect of the leading scientific approaches to the functioning of STEM-education is characterized: multidisciplinary, pluridisciplinary, interdisciplinary, transdisciplinary. Within the latter approach, traditional didactic scientific approaches to the construction of educational content remain relevant, provided that they focus primarily on active independent and creative activity, which is leading in the process of learning and developing students'skills and abilities of self-education, which are key in the list of leading life and career "Skills of the XXI century». Such traditional didactic approaches to the construction of educational content and independent activity of students are: interdisciplinary, integration, differentiation and individualization. The essential features of specific qualities that students must learn in the process of obtaining STEM-education are revealed and characterized: the formation of the need for learning, the formation of motivation to learn, the formation and development of interest. The second part of the article will be published in the next issue of the journal.

Key words: STEM-education, didactic component, general secondary education institutions, competencies, scientific approaches, students.

Постановка проблеми. Процеси модернізації національної системи освіти спричинені насамперед соціально-економічними змінами в державі, входженням України у європейський та світовий освітній простір, актуалізували потребу переосмислення мети і завдань освіти, виховання, розвитку і соціалізації підростаючого покоління з позиції демократизації і гуманізації суспільного життя та визнання прав і свобод дитини.

Аналіз наукових досліджень і публікацій. Вирішенню актуальних проблем упровадження інноваційних технологій (таких як STEM-освіта) в сучасний освітній простір держави присвятили наукові праці В. Величко, М. Головань, Ю. Горошко, А. Сршов, Х. Гонсалес, Дж. Куензі, Н. Морел та ін. У відповідності до обгрунтованих ними підходів упровадження STEM-освіти можемо зробити висновок, що це «...напрям, який визначає відповідний 
педагогічний процес (технологію) ефективного формування і розвитку освітніх потреб, інтересів і мотивів, розумово-пізнавальних і творчих якостей учнів, рівень яких визначає конкурентну спроможність на сучасному ринку праці: здатність і готовність до розв'язання комплексних задач (проблем), критичного мислення, творчості, когнітивної гнучкості, співпраці, здійснення самостійної творчої й інноваційної діяльності» [6].

Водночас дидактична складова ефективності упровадження STEM-освіти у закладах загальної середньої освіти, зокрема під час вивчення шкільного курсу географії, є недостатньо дослідженою.

Метою статті $\epsilon$ виокремлення й характеристика дидактичної складової застосування STEM-освіти у закладах загальної середньої освіти, зокрема на уроках географії.

Виклад основного матеріалу. Після підписання Україною Меморандуму про створення Коаліції STEM-освіти 16 вересня 2015 року питання упровадження елементів STEM-освіти в сучасних закладах середньої освіти набуло незаперечної актуальності, оскільки ії упровадження у широку педагогічну практику має забезпечити ефективне розв'язання важливих навчально-виховних, розвивальних і соціалізуючих проблем, створення умов для формування й розширення освітніх потреб дітей, посилення мотивації й інтересу до здобуття нових системних наукових знань, вироблення умінь і навичок критичного мислення та розвитку творчого потенціалу. Розвиток цього освітнього напряму набув ще більшої значущості після ухвалення 5 серпня 2020 року Кабінетом Міністрів України «Концепції розвитку природничо-математичної освіти (STEM-освіти)», реалізація якої передбачена до 2027 року. Сутність останньої розглядається як система природничої і математичної освіти, що має на меті гармонійний розвиток особистості завдяки формуванню провідних життєво важливих компетентностей, природничо-наукової картини світу, світоглядних позицій і життєвих цінностей. Саме у цьому контексті абревіатура STEM розшифровується як: $\mathrm{S}$ - science (природничі науки), T - technology (технологіï), E - engineering (інженерія або технічна творчість), M - mathematics (математика). Сьогодні актуальності набув ще один напрям цієї системи освіти: $\mathrm{A}$ - art (мистецтво), що відповідно доповнює зазначену абревіатуру, позначається як STEM and Arts і трактується як STEAM-освіта. У зв'язку з цим актуальними напрямами STEM and Arts $€$ промисловий дизайн, архітектура, індустріальна естетика тощо.

Крім того, у вітчизняних нормативно-правових документах і науково-методичній літературі в галузі загальної середньої освіти розглядається усталений нині термін STEM-освіта як сучасний інноваційний комплексний міждисциплінарний підхід до побудови навчально-виховного, розвивального і соціалізуючого змісту, відповідних форм і методів його ефективної реалізації. Провідними конструктами цього освітнього напряму є логічно поєднані природничі науки 3 технологіями, інженерією, мистецтвом і математикою. Основною концептуальною ідеєю його запровадження у педагогічну практику визначається створення умов для ефективного розв'язання зростаючою особистістю, переважно самостійно чи за супроводу вчителя та батьків, життєво важливих для неї проблем, формування потреб, мотивів та розвитку інтересу до здобуття знань, завдяки інтеграції навчальних предметів у єдину цілісну систему.

3 огляду на зазначене вище та відповідно до Концепції реалізації державної політики у сфері реформування загальної середньої освіти «Нова українська школа» на період до 2029 року, постає «... завдання формування освіченої, вихованої, соціалізованої інноваційно спрямованої креативної особистості» [8].

Аналіз зазначеного вище дає підстави стверджувати, що природничо-математична освіта (STEM-освіта) має стати не лише пріоритетом, але й «...складовою державної політики з підвищення рівня конкурентоспроможності національної освіти, а відтак - економіки та розвитку людського капіталу, одним з основних чинників інноваційної діяльності у сфері освіти, що відповідає запитам соціального розвитку, розбудови економіки та потребам сучасного українського суспільства» [13].

У теоретико-прикладному аспекті сутність STEM-освіти сьогодні базується на таких узагальнених сучасних наукових підходах:

- мультидисциплінарному, коли декілька навчальних предметів і практик фокусуються на вирішенні однієї навчальної проблеми, одного навчального чи практичного завдання;

- плюридисциплінарному, коли здійснюється поєднання споріднених навчальних предметів і практик для створення інтелектуального поля побудови інтегрованого знання;

- інтердисциплінарному, коли розгляд сутності (тематики, декількох конкретних проблем чи практичних завдань) з одного навчального предмета і однієї практики здійснюється крізь призму інших;

- трансдисииплінарному, коли здійснюється розгляд і вирішення реальної місцевої проблеми (соціальної, екологічної, природоохоронної, краєзнавчої, суспільно корисної тощо), що за своєю сутністю виходить за межі здобутих знань учнів із навчальних предметів закладу загальної середньої освіти. При цьому вимагає самостійного пошуку учнями додаткових знань, що мають забезпечити ефективність вирішення ними цієї проблеми. За нашим переконанням, саме цей підхід найбільше відповідає вимогам реформування сучасної загальної середньої освіти, зокрема і географічної, та положенням Закону України «Про освіту» [10] i Концепції Нової української школи [8; 9].

Відтак, ключова ідея трансдисциплінарності у межах сучасної загальної середньої освіти полягає у науково вивіреному й обгрунтованому об'єднанні змісту різних навчальних предметів, а головне конкретної практики, і спрямовується на розв'язання учнями самостійно чи за супроводу вчителя реальних (індивідуально й соціально значущих) життєво важливих як для них, так і для оточуючих конкретних проблемних ситуацій. Частково трансформуючи думку Дж. Кляйна у контексті проблеми нашої статті, можемо зробити висновок, що застосування трансдисциплінарного підходу в сучасній освіті дає змогу «...актуалізувати нереалізований ii інтелектуальний потенціал $\mathrm{i}$, як наслідок, підвищити ефективність освіти на всіх рівнях ііі здійснення» $[15$, с. 4$]$.

Крім цього, застосування трансдисциплінарного підходу в сучасній освітній галузі передбачає створення умов для ефективного поєднання індивідуального, парного і групового навчання у формах і технологіях, що $є$ комфортними для учня у процесі їх самостійного застосування. Тобто, мова йде про наявність сучасних потреб переходу від традиційного навчання учнів у закладах загальної середньої освіти до їхнього самостійного учіння, що підвищує рівень мотивації, а головне, відповідальності за його результати [12]. 
Крім зазначеного вище, у межах трансдисциплінарного підходу актуальними залишаються традиційні дидактичні наукові підходи до побудови навчального змісту, за умови їх «...орієнтації, в першу чергу, на активну самостійну і творчу діяльність, що $\epsilon$ провідною у процесах навчання та вироблення в учнів умінь і навичок самоосвіти, які є ключовими в переліку провідних життєвих і кар'єрних «Навичок XXI століття» [17]. ми є:

Отже, такими традиційними науковими підхода-

- міжпредметний. За результатами філософського аналізу сутність категорії «міжпредметні зв'язки» у сучасній філософії освіти та педагогічній науці трактується як: дидактична форма гносеологічного принципу системності у процесі навчання, що забезпечує побудову цього процесу як педагогічної системи; як самостійний принцип побудови дидактичних систем локального характеру в предметній системі навчання. За своєю структурою означена категорія включає: загальнопедагогічний аспект, у межах якого міжпредметні зв'язки трактуються як дидактична умова, що забезпечує не тільки формування системних наукових знань учнів, а й розвиток їхніх пізнавальних здібностей, активності, інтересу, творчості у здійсненні розумових операцій; методичний аспект характеризує процес удосконалення змісту, форм, методів, прийомів і способів конструювання змісту окремих навчальних предметів 3 метою їх подальшого структурування і поєднання на рівні окремого нового інтегрованого знання [3, с. 14-17].

На думку І. Звєрєва, міжпредметний характер сучасної освіти учнів різного віку «...дає змогу подолати розрив між природничими і гуманітарними циклами навчальних предметів, з одного боку, в результаті поступового застосування знань про природу під час вивчення суспільних явищ i, з другого, гуманізації природознавства у процесі навчання» [3].

Узагальнюючи, можемо констатувати, що міжпредметні зв'язки є педагогічною категорією для позначення інтеграційних зв'язків між об'єктами, явищзами та прочесами реальної дійсності, щуо знайшли своє відображення у змісті, формах і методах освітнього процесу й виконують освітню, виховну, розвивальну і сочіалізуючу функиії в їхній органічній єдності та формуванні локальних умінь і навичок переносу їх $у$ нові проблемні ситуащіï. Саме такий підхід, на думку В. Червонецького, «...дає змогу об'єднати навчальні предмети в уніфіковану навчально-виховну систему, що сприяє формуванню в учнів цілісного уявлення про навколишнє середовище» $[14$, с. 45];

- інтеграційний. За своєю сутністю інтеграція розглядається насамперед як інтеграція інтелектуального ресурсу (конкретних базових наукових знань, відповідних умінь і навичок та соціального досвіду учнів) у змісті навчальних як природничих, так і гуманітарних предметів закладів загальної середньої освіти. Таким чином передбачає непросте поєднання певних логічно пов'язаних між собою знань, які механічно запозичуються з декількох предметів (географія, астрономія, математика, біологія, хімія, фізика тощо) і конструктивно вибудовуються автором у змісті інтегрованої навчальної програми 3 метою створення інтелектуального поля, що має забезпечити вирішення конкретної практичної навчальної, виховної, розвивальної чи соціалізуючої проблеми. Крім того, ставиться завдання створення нового міжпредметного освітнього простору, у межах якого відбувається детермінація якісно нового освітнього продукту, що за своїми сутнісними ознаками набуває автономності та обов'язково цілісності, системності та логічної завершеності. Зважаючи на це, інтеграція знань сприяє трансформації освітнього процесу закладів загальної середньої освіти у комфортне для учня середовище пізнання довкілля, власного розвитку, саморозвитку та самостановлення.

Актуальним у контексті схарактеризованих вище наукових підходів щодо запровадження в закладах загальної середньої освіти, зокрема і на уроках географії, STEM-освіти, є реалізація низки ключових цільових організаційно-педагогічних пріоритетних підходів, що підвищують ефективність процесів формування інтелектуальної та духовно-моральної сфер зростаючої особистості. Насамперед це комплексне застосування у розв'язанні проблем якості сучасної шкільної географічної освіти наступних наукових підходів: особистісно зорієнтованого підходу - спрямованого на створення «ситуації успіху» у власній життедіяльності; особистісно діяльнісного - спрямованого на практичну соціально-значущу діяльність, у процесі якої учнем реалізуються на практиці здобуті знання за рахунок сформованих умінь та навичок; ціннісно-мотиваційного - орієнтованого на формування системи цінностей і життєво важливих мотивацій щодо власного розвитку і саморозвитку; соціально адаптаційного, що сприяє адаптації дитини до соціальних викликів і загроз, а у подальшому забезпечує процеси соціалізації зростаючої особистості, іï допрофесійного самовизначення та самореалізації [16, с. 2].

Окреме важливе місце у процесах запровадження на уроках географії STEM-освіти належить процесам диференціації у побудові та реалізації змісту шкільної географічної освіти, оскільки процес інтегрування змісту освіти, виховання, розвитку і соціалізації учнів у сучасних закладах загальної середньої освіти має передбачати обов'язкове його структурування 3 позиції диференціації. У своїй структурі диференціація як категорія дидактики розглядається у двох взаємопов'язаних площинах як «зовнішня диференціація» та «внутрішня диференціація». Сутність «зовнішньої диференціації» полягає в організації освітнього процесу закладу загальної середньої освіти, за якої для задоволення різнобічних освітніх запитів, інтересів, здібностей і нахилів учнів створюються спеціальні диференційовані класи, або ж навіть заклади освіти, тоді як сутність «внутрішньої диференціації» складає така організація освітньо-виховного процесу, за якої розвиток індивідуальності здійснюється в умовах застосування інноваційних форм і методів та технологій у традиційній школі. За такого підходу диференціація $€$ надзвичайно перспективним підходом до поглибленого самостійного вивчення учнями навчального матеріалу чи здійснення самостійного дослідження об’єктів чи явищ довкілля у відповідності до їхніх вікових та індивідуальних можливостей. Отже, інтегрування знань учнів поряд із їх глибокою диференціацією та узагальненням здобутих знань в освітньому процесі закладів загальної середньої освіти дає змогу повною мірою сформувати комплексні й системні теоретичні наукові знання, виробити вміння і навички розуміння таких важливих категорій, як цілісність, системність, взаємозв'язок, роль і місце людини у довкіллі;

- індивідуалізація сьогодні розглядається як один із провідних напрямів побудови освітнього процесу у закладах загальної середньої освіти, зокрема, запровадження STEM-освіти на уроках географії. 
Оскільки за цих умов є можливість чітко визначити й схарактеризувати особистісні замовлення, інтереси, потенційні можливості й нахили дітей та їхніх батьків, що постійно розвиваються і варіюються, в чому і простежується безперервна динамічність означеного напряму освіти. Зважаючи на це, індивідуалізація процесу освіти, виховання, розвитку й соціалізації зростаючої особистості передбачає:

- індивідуально орієнтовану допомогу учням в усвідомленні ними сутності власних освітніх потреб, інтересів, цілей навчання і значущості здобутих ними знань;

- створення умов для вільної реалізації особистісних здібностей і потенційних можливостей у конкретній як індивідуальній, так і колективній соціально значущій діяльності;

- підтримку учня у творчій самореалізації і самостановленні;

- підтримку і допомогу учневі у процесах рефлексії.

Це визначає необхідність створення комфортних і партнерських суб'єкт-суб'єктних та об'єкт-суб'єктних зв'язків і взаємозалежностей в учнівсько-педагогічному колективі закладу загальної середньої освіти, що має забезпечити їх навчально-виховну, розвивальну і соціалізуючу ефективність. Саме за цих умов набуває актуальності спрямованість конкретної педагогічної дії в освітньому процесі на кожну особистість учнівського колективу, включення iї в систему широких комунікативних зв'язків як за горизонталлю (між ровесниками - учнями одного чи кількох класів), так і за вертикаллю (між ровесниками і вчителями, молодшими і старшими учнями, їхніми батьками та громадою). Однак визначальним чинником індивідуалізації освітнього процесу є розвиток інтелектуальної, ціннісно-мотиваційної та діяльнісно-практичної сфери конкретної особистості на кожному з етапів самостійного навчання, формування іiі життєвого досвіду взаємодії 3 навколишнім середовищем, вміння знаходити доцільні рішення і дії у подоланні як особистісних, так і суспільно значущих проблем своєї місцевості. А це безпосередньо забезпечує формування ще й гуманістичної зрілості дитини й, головне, іï «...соціальної активності та відповідальності за власні вчинки, дії і діяльність у соціумі» [4].

За таких умов пізнання себе як особистості складається $з$ уявлення дитини про позитивні і негативні риси свого характеру, поведінки чи діяльності в соціоприродному середовищі, своєї ролі в учнівсько-педагогічному колективі класу, серед однолітків та у цілому в закладі загальної середньої освіти. Саме залучення учнів до конкретної навчально-пізнавальної, дослідницької і конструкторської діяльності є практичним втіленням результатів останньої у конкретній суспільно корисній, масовій чи природоохоронній роботі, а також створює передумови ефективного формування вмінь і навичок осмислювати і відносно адекватно оцінювати себе, свої інтереси, здібності та дії, свій внесок у вирішення загальної справи учнівським колективом. Тобто забезпечується єдність $і$ цілісність характерних рис особистості, їх проявів у практичній діяльності, що є однією 3 найважливіших ознак індивідуальності.

Отже, запровадження STEM-освіти передбачає визнання центром освітньо-виховного, розвивального і соціалізуючого процесу у закладах загальної середньої освіти саме учня, який переважно самостійно чи за допомоги вчителя або ж старших учнів вирішує поставлені перед ними проблемні практичні завдання.
За цих умов учень має навчитися самостійно знаходити ефективні напрями вирішення навчальних проблем, застосовуючи засвоєні знання, сформовані вміння i навички, або ж здійснювати пошук необхідних нових знань, які допоможуть йому переважно самостійно вирішити поставлене завдання, скорегувати результати своєї праці і навіть виправити допущені ним помилки.

У зв'язку з цим особливої актуальності набуває положення Концепції Нової української школи про те, що учень повинен навчитися самостійно здобувати знання і застосовувати їх у власній життєдіяльності, а учитель - самостійно підвищувати свій фаховий рівень. Крім того, для ефективного застосування STEM-освіти учитель географії має досконало знати програмний матеріал інших шкільних предметів, що використовується під час створення інтегрованих авторських навчальних програм, конкретних тем чи практичних завдань, що будуть вирішуватись учнями самостійно чи за його педагогічного супроводу. Крім цього, особливої актуальності у реалізації змісту інтегрованої, а головне, практично спрямованої навчальної програми набувають сформовані вміння та навички: застосовування різноманітних форм, методів, засобів та прийомів організації освітньо-виховного процесу; співпраці 3 іншими учителями-предметниками 3 метою формування в учнів системних наукових знань, спільних для багатьох навчальних предметів закладу загальної середньої освіти; організації і проведення конкретної навчально-пізнавальної, дослідницької і конструкторської діяльності та суспільно корисної, масової чи природоохоронної роботи у межах позаурочних і позакласних заходів, у змісті яких найбільш ефективно буде реалізований практичний досвід учнів.

Таким чином, запровадження STEM-освіти детермінує в сучасному освітньо-виховному процесі закладів загальної середньої освіти не стільки оволодіння учнями різного віку теоретичними знаннями, хоча це беззаперечно важливо, а формування вмінь i практичних навичок застосовування цих здобутих i засвоєних теоретичних знань безпосередньо у власній практичній діяльності. Зміст уроку трансформується у його практичну площину, у межах якої учні можуть реально, а головне ефективно застосувати самостійно засвоєні ними теоретичні знання у розв'язанні конкретних навчальних, пошукових і дослідницьких суто практичних завдань, у процесі здійснення як індивідуальної, так і колективної суспільно корисної, масової чи природоохоронної роботи.

Ураховуючи зазначене вище, можемо зробити висновок, що конкретною метою застосування STЕM-освіти у закладі загальної середньої освіти є: поглиблення і розширення географічних (фізико-географічних, краєзнавчих, економічних, екологічних, соціальних та інших знань) про свій рідний край, місто чи окреме селище; розвиток аналітичних творчих здібностей і творчого потенціалу та креативного мислення учнів різного віку; формування їхньої здатності до самостійної і колективної навчально-пізнавальної, дослідницької і конструкторської діяльності та конкретної суспільно корисної, масової і природоохоронної роботи, що має ще й соціальну значущість; розвиток кмітливості, витривалості, вміння аргументовано обгрунтовувати й відстоювати власну думку, засвоювати правила культури спілкування, розвивати комунікабельність, уміння працювати в групі; формування поваги та любові до рідної країни та малої батьківщини.

Отже, можемо констатувати, що впровадження STEM-освіти в закладах загальної середньої освіти, 
крім зазначеного вище, спрямовується на: формування і розвиток насамперед критичного мислення; формування умінь і навичок комунікації українською та іноземними мовами; виховання інформаційної грамотності та використання IКТ у процесі організації і здійснення спостережень, проєктної, пошукової і дослідницької діяльності; формування вмінь створювати інтерактивні моделі; розвиток навичок самостійності, підприємливості, відповідальності та ефективної співпраці в колективі.

Крім того, специфічними якостями, які мають засвоїти здобувачі освіти у процесі упровадження STEM-освіти, є:

- формування потреби у навчанні. Ефективність цих процесів безпосередньо залежить від усвідомлення учнями ролі і місця здобутих знань, сформованих умінь і навичок у їхній конкретній самостійній чи колективній навчально-пізнавальній, дослідницькій і конструкторській діяльності та суспільно корисній, масовій чи природоохоронній роботі в умовах освітньо-виховного процесу закладу загальної середньої освіти чи за його межами, а головне - у майбутньому. На думку О. Леонтьєва, «... істинна, а не формальна характеристика психічного розвитку дитини не може бути відділеною від розвитку його реального ставлення до світу, а отже, від змісту його відношення і потреб як сьогодні, так і усвідомлення своїх майбутніх домагань» [5].

Саме у здобутті якісних знань та їх ефективного застосування у власній майбутній професійній діяльності в умовах ринку праці визначається рівень готовності учнівської молоді до «...виконання відповідних соціальних ролей і у майбутньому дорослому житті» [2, с. 57];

- формування мотивації до навчання, насамперед до самостійного здобуття якісних знань, формування вмінь і практичних навичок їх застосування у різноманітних життєво важливих навчальних, побутових, соціально значущих проблемних ситуаціях У контексті останнього різноманітні умови життєдіяльності особистості в іiі об’єктивному життєвому просторі породжують життєві потреби, які за своєю сутністю є «...спонукою і водночас метою діяльності індивіда» [1];

- формування $i$ розвиток інтересу. Критерієм останнього є потреба і мотивація до здійснення конкретної самостійної чи колективної навчально-пізнавальної, дослідницької і конструкторської діяльності та суспільно корисної, масової чи природоохоронної роботи як в умовах освітньо-виховного процесу закладу загальної середньої освіти, так і за його межами у соціоприродному середовищі. Отже, глибоке осмислення та засвоєння теоретичного матеріалу, пов'язаного з ним експериментального, здобутого та, що найважливіше, реалізованого самими учнями у процесі практичної роботи, «...не може здійснюватися успішно, якщо не розвинутий інтерес і потреба в знаннях» [11, с. 24-38].

Висновки. Зміст означеної статті не вичерпує можливостей побудови інноваційного навчального змісту у процесі запровадження STEM-освіти у закладах загальної середньої освіти, зокрема на уроках географії. Зважаючи на це, у змісті другої частини цієї публікації буде здійснено розкриття інших специфічних якостей, які мають засвоїти учні у процесі впровадження цього напряму освіти та окремих методик трансформації уроку географії у його суто практичну площину.

(Продовження у наступному номері журналу)

\section{СПИСОК ВИКОРИСТАНОЇ ЛІТЕРАТУРИ}

1. Бех І. Д. Виховання особистості : у 2 кн. Кн. 1. Особистісно орієнтований підхід: теоретико-технологічні засади : наукове видання. Київ : Либідь, 2003. 280 с.

2. Бех І. Д. Особистість у просторі духовного розвитку : навч. посіб. Київ : Академвидав, 2012. 256 с.

3. Зверев И. Д. Охрана природы и образование. Образование в современном мире / под ред. М. И. Кондакова. Москва : Просвещение, 1998. 238 с.

4. Капіруліна С., Паламарчук Л. Міжпредметні зв'язки на уроках географії в модульно-розвивальній системі навчання. Географія та основи економіки. 2002. № 2. C. 14-17.

5. Кравченко Т. В. Соціалізація дітей шкільного віку у взаємодії сім’ї і школи : монографія. Київ : Фенікс, 2009. 482 c.

6. Леонтьев А. Н. Деятельность, сознание, личность. Москва : Смысл, 2005. 432 с.

7. Методичні рекомендації щодо впровадження STEM-освіти у загальноосвітніх та позашкільних навчальних закладах України на 2017/2018 навчальний рік. URL: https://imzo.gov.ua/2017/07/13/ lyst-imzo-vid-13-07-2017-21-1-10-1410-metodychnirekomendatsiji-schodo-vprovadzhennya-stem-osvity-uzahalnoosvitnih-tapozashkilnyh-navchalnyh-zakladahukrajiny-na-2017-2018-n-r/ (дата звернення: 13.10.2020).

8. Нова українська школа / М-во освіти і науки України. URL: https://mon.gov.ua/ua/tag/novaukrainska-shkola (дата звернення: 10.02.2020).

9. Нова українська школа. Концептуальні засади реформування середньої школи / М-во освіти і науки України. URL: https://mon.gov.ua/storage/app/ media/zagalna\%20serednya/nova-ukrainska-shkolacompressed.pdf (дата звернення: 10.02.2020).

10. Про освіту : Закон України від 05.09.2017 р. № 2145-VIII. URL: http://search.ligazakon.ua/ldoc2. nsf/link1/T172145.html (дата звернення: 10.02.20̄20).

11. Пустовіт Г. П. Інтерактивні методи навчання i виховання у позашкільному навчальному закладі. Інноватика у вихованні : зб. наук. пр. / упоряд. О. Б. Петренко ; ред. кол. : О. Б. Петренко, Н. М. Гринькова, Т. С. Ціпан та ін. Рівне : РДГУ, 2015. Вип. 2. С. 24-38.

12. Трансдисциплинарность. Вікіпедія : вебсайт. URL: https://ru.wikipedia.org/wiki/\%D0\%A2\%D1\%80\% D0\%B0\%D0\%BD $\%$ D1\%81\%D0\%B4\%D0\%B8\%D1\%8 $1 \% \mathrm{D} 1 \% 86 \% \mathrm{D} 0 \% \mathrm{~B} 8 \% \mathrm{D} 0 \% \mathrm{BF} \% \mathrm{D} 0 \% \mathrm{BB} \% \mathrm{D} 0 \% \mathrm{~B} 8 \% \mathrm{D} 0$ $\%$ BD $\%$ D0 $\%$ B0\%D1\%80\%D0\%BD $\%$ D0\%BE $\%$ D $1 \% 81$ $\% \mathrm{D} 1 \% 82 \% \mathrm{D} 1 \% 8 \mathrm{C}$ (дата звернення: 22.10.2020).

13. Уряд ухвалив концепцію STEM-освіти до 2027 року. URL: https://pedpresa.com.ua/203007uryad-uhvalyv-kontseptsiyu-rozvytku-stem-osvity.html (дата звернення 28.09.2020).

14. Червонецький В. В. Екологічна освіта учнів у школах країн європейського регіону та північної Америки : монографія. Луганськ : Вид-во СНУ ім. В. Даля, 2005. 312 с.

15. Klein J. Th. Transdisciplinarity: Joint Problem Solving Among Science, Technology, and Society: An Effective Way for Managing Complexity. Birkhäuser, 2001. $332 \mathrm{p}$.

16. Osborn T. Beyond the Boundaries: A Transdisciplinary Approach to Learning and Teaching. Westport : Greenwood Publishing Group, 2003. 174 p.

17. Trilling, B., Fadel, C. 21 st Century skills: Learning for Life in Our Times. USA: Jossey-Bass Publishing, 2009. 243 p.

Дата надходження до редакиї: 22.11.2020 p. 